\title{
Minimization of Copper Losses in Copper Smelting Slag During Electric Furnace Treatment
}

\author{
PASCAL COURSOL,${ }^{1,4}$ NUBIA CARDONA VALENCIA, ${ }^{2}$ \\ PHILLIP MACKEY ${ }^{3}{ }^{3}$ STACY BELL, ${ }^{2}$ and BOYD DAVIS ${ }^{2}$ \\ 1.--Barrick Gold Corporation, Toronto, ON, Canada. 2.-Kingston Process Metallurgy, Kingston, \\ ON, Canada. 3.-P. J. Mackey Technology Inc., Kirkland, QC, Canada. 4.-e-mail: pcour- \\ sol@barrick.com
}

In the quest to achieve the highest metal recovery during the smelting of copper concentrates, this study has evaluated the minimum level of soluble copper in iron-silicate slags. The experimental work was performed under slag-cleaning conditions for different levels of $\mathrm{Fe}$ in the matte and for a range of $\mathrm{Fe} / \mathrm{SiO}_{2}$ ratios in the slag. All experiments were carried out under conditions where three phases were present (copper-matte-slag), which is the condition typically prevailing in many slag-cleaning electric furnaces. The $\% \mathrm{Fe}$ in the electric furnace matte was varied between $0.5 \mathrm{wt} . \%$ and $11 \mathrm{wt} . \%$, and two different $\mathrm{Fe} / \mathrm{SiO}_{2}$ ratios in the slag were used (targeted values were 1.4 and 1.6). All experiments were performed at $1200^{\circ} \mathrm{C}$. From thermodynamic considerations, from industrial experience, and from the results obtained in this study, the minimum soluble copper content in the electric furnace slag is expected to be near $0.55 \mathrm{wt}$.\% $\mathrm{Cu}$. This level does not account for a portion of the copper present as mechanically entrained matte/metal droplets. Taking this into account, the current authors believe an overall copper level in discard slag between 0.7 wt.\% and 0.8 wt.\% can be obtained with optimal operating conditions. For these conditions, the copper losses in the slag are roughly $75 \%$ as dissolved copper and $25 \%$ as entrained matte and copper. Such conditions include operating the electric furnace at metallic copper saturation, maintaining the $\% \mathrm{Fe}$ in the electric furnace matte between $6 \mathrm{wt} \%$ and $9 \mathrm{wt} . \%$, not exceeding a slag temperature of $1250^{\circ} \mathrm{C}$, and controlling the $\mathrm{Fe} / \mathrm{SiO}_{2}$ ratio in the smelting furnace slag at $\leq 1.5$. In addition, magnetite reduction needs to be performed efficiently during the slag-cleaning cycle so as to maintain a total magnetite content of $\leq 7 \mathrm{wt} . \%$ in the discard slag. The authors further consider that under exceptionally well-controlled conditions, a copper content in electric furnace discard slag between $0.55 \mathrm{wt} . \%$ and $0.7 \mathrm{wt} . \%$ can be obtained, by minimizing entrained matte and copper solubility in the discard slag.

\section{INTRODUCTION}

During the last few decades, the pyrometallurgical processes used for cleaning copper smelting slags have been steadily optimized. The electric furnace or rotary slag-cleaning furnace are now generally used to perform this task, giving a level of copper in discard slag typically in the range of $0.55 \mathrm{wt} . \%$ and 1.3 wt.\%, with most plants reporting copper losses in the discard slag in the range of $0.8-1.0 \mathrm{wt} . \%$.

A significant portion of the copper loss in discard slag from such furnaces is present as dissolved copper in the form of $\mathrm{Cu}_{2} \mathrm{O}$, especially toward the higher oxygen potential range of operating furnaces (higher matte grades, $\mathrm{Fe} / \mathrm{SiO}_{2}>1.5$ ), or in the form of soluble copper oxysulfides when the slag is equilibrated with mattes of lower grade (mattes $<65 \% \mathrm{Cu}$ or $>12 \% \mathrm{Fe}$ ). The balance of the copper loss in commercial discard slag is as mechanically entrained copper matte and metallic copper. The latter forms can be minimized in part by maintaining a low magnetite level in the treated slag and by following a systematic standard operating procedure for the slag-cleaning furnace, which also 
provides for an acceptable settling time. These two forms of copper loss (soluble and entrained) are equally important in regard to achieving acceptably low copper losses. The thermodynamic limitations for reaching the lowest copper level are not well known, and there is incomplete agreement in the literature regarding the lowest attainable soluble copper level excluding entrainment. A good understanding of the theoretical achievable limits will allow one to see how far a given process is from ideal conditions.

The current investigation provides an experimental measurement of the soluble copper level in copper smelting slags in equilibrium with matte and metallic copper. These are the conditions prevailing in many electric slag-cleaning furnaces and in some rotary slag-cleaning furnaces. The ultimate objective of the current work was to evaluate the minimum level of soluble copper that can be achieved in electric furnace slag-cleaning operations under conditions when a small layer of molten copper is present.

Given the ever-rising cost of energy and the current attractive copper price, a number of plants are considering the capital investment required to change from pyrometallurgical slag cleaning to slow cooling of slag, milling, and flotation. While each plant's situation is different, such a move would appear to be interesting from the perspective of operating costs, metal recovery, and minor element deportment. Nevertheless, to carry out a proper techno-economical evaluation of such a transition, reliable information on the best achievable copper loss in pyrometallurgical slag cleaning is required. In this study, the authors present the experimental data obtained from laboratory experiments performed at Kingston Process Metallurgy, Ontario, Canada, and they provide the interpretation of the results in part based on their wide industrial experience.

\section{PRIOR WORK AND BRIEF HISTORICAL BACKGROUND}

As the main factor affecting the copper recovery at copper smelters, the copper content in discard slag has always been important to the smelter operator. This topic, therefore, has been the subject of a large number of studies. ${ }^{1-8}$ Prior to the introduction of modern flash and bath smelting processes commencing in the 1950 s to $1960 \mathrm{~s}$, the reverberatory furnace was the workhorse of the copper industry, and converter slag was returned to the reverberatory furnace for converter slag cleaning. Much activity with respect to slag copper losses in the period of the $1900 \mathrm{~s}$ to $1960 \mathrm{~s}$ was therefore focused on reverberatory slag. ${ }^{1,2}$ Reverberatory furnace matte grades were typically in the range of $30-40$ wt.\% $\mathrm{Cu}$, with a number of operations in South America and Africa operating up to $70 \mathrm{wt} . \%$
$\mathrm{Cu}$ in matte. It was common to relate the copper level in reverberatory slag to the matte grade, with the best operations reporting a $\% \mathrm{Cu}_{\text {slag }} / \% \mathrm{Cu}_{\text {matte }}$ ratio between 0.010 and $0.013 .^{2}$ Thus, for a matte grade of 35 wt.\% $\mathrm{Cu}$, such well-operated smelters would have a $\mathrm{Cu}$ level in slag ranging from 0.35 wt.\% to 0.46 wt.\%. Many smelters, however, reported higher slag values. ${ }^{2,8}$

At this time, it was recognized that copper in reverberatory slag was as dissolved copper, with imprecise information on the form of this copper, and some as suspended matte in the slag. ${ }^{2}$ Spira and Themelis ${ }^{2}$ experimentally measured entrained copper levels in reverberatory slag using brominemethanol as an extractant. They concluded that over $70 \%$ of the total copper in these slags was present as soluble copper. The oxygen content of the matte and the sulfur content of the slag were also determined in this study. Parallel with improvements in operating performance, the thermodynamics of copper smelting was also established over this period. ${ }^{3}$

With the subsequent introduction of flash and bath smelting technologies, wherein smelter matte grades of $60-70 \mathrm{wt} . \% \mathrm{Cu}$ were becoming common, new technologies such as the electric slag-cleaning furnace and the rotary slag-cleaning furnace evolved to replace the slag-cleaning function of reverberatory furnaces. Alternatively, slow cooling of slags followed by milling and flotation also became established technology. Three seminal studies during this era subsequently established the thermodynamics of copper smelting with particular attention to slag copper losses in the new high-grade matte operations. Yazawa and Eguchi ${ }^{4}$ at Tohoku University in Japan published a series of papers related to the thermodynamics of copper smelting. Schenalak and Imris, ${ }^{5}$ at the University of Kosice, Slovakia, for the first time quantified the oxide and sulfide forms of copper dissolved in slags, in particular in slags from new continuous smelting and converting processes. Nagamori ${ }^{6}$ also independently identified and quantified these forms of copper in slag. Thus, by the mid-1980s, a solid basis for understanding copper losses in slags from flash and bath processes and associated slag-cleaning operations was established. ${ }^{7}$ However, the minimum levels of soluble copper under slag-cleaning conditions, such as in the electric furnace or the rotary slag-cleaning operation, are still not well established. The purpose of the current work is to establish this minimum level of the soluble copper in these types of slags.

\section{METHODOLOGY}

\section{Fixing all Degrees of Freedom}

The Gibbs phase rule stipulates that all degrees of freedom in a chemical system are fixed when the relationship $F=C-P+2$ is satisfied. Here, $F$ is 
the number of degrees of freedom in the system, $C$ is the number of components, and $P$ is the number of distinct phases. There are five major components (Fe-Cu-O-S-Si) and three phases (copper, matte, and slag) in the current system; hence, 4 degrees of freedom would need to be fixed for calculations or experiments.

In an industrial slag-cleaning furnace, the temperature is typically held between $1200^{\circ} \mathrm{C}$ and $1275^{\circ} \mathrm{C}$, the total pressure is constant at 1 bar, the $\% \mathrm{Fe}$ in matte is kept between $1 \mathrm{wt} . \%$ and $12 \mathrm{wt} . \%$, and the $\mathrm{Fe} / \mathrm{SiO}_{2}$ ratio in the slag is normally between 1.2 and 1.8, depending on the smelting conditions. Therefore, for the current experiments, the temperature, the total system pressure, the $\% \mathrm{Fe}$ in the matte, and the $\mathrm{Fe} / \mathrm{SiO}_{2}$ ratio of the slag were all fixed. It is noted that in the current system with three phases present (copper-matte-slag), the partial pressure of oxygen is automatically fixed, and subsequently, there is no need to independently fix the $p\left(\mathrm{O}_{2}\right)$ in the gas phase. Thus, the equilibrium between $\mathrm{Fe}$ and $\mathrm{FeO}$, as illustrated by reaction 1 fixes the $p\left(\mathrm{O}_{2}\right)$ in the system. This allowed the experiments to conveniently be carried out under an inert gas atmosphere (argon was used).

$$
[\mathrm{Fe}]_{\mathrm{Cu}}+1 / 2 \mathrm{O}_{2}=[\mathrm{FeO}]_{\text {Slag }}
$$

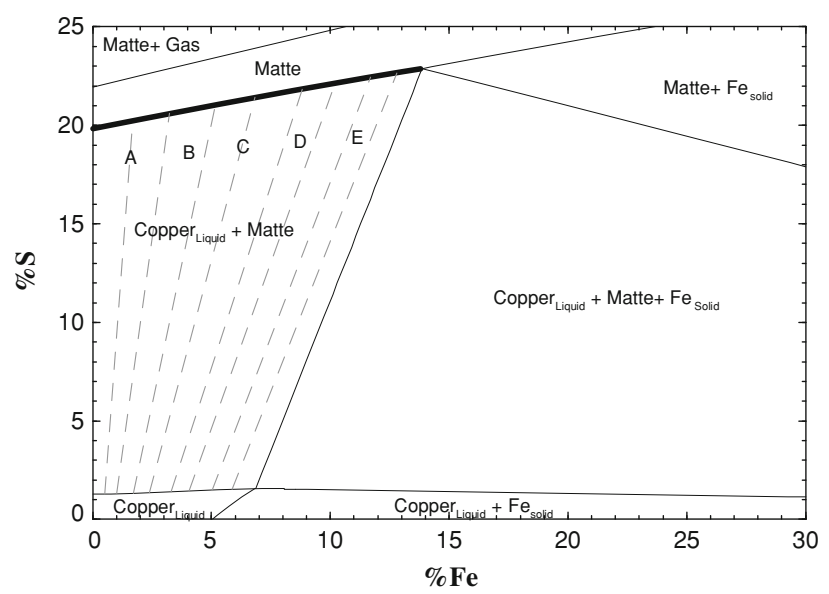

Fig. 1. The copper rich side of the Cu-Fe-S phase diagram at $1200^{\circ} \mathrm{C}$ as calculated by Factsage. ${ }^{8}$ The dark, heavy line indicates the matte composition in equilibrium with molten copper. Experimental points $A$ through $E$ were chosen inside the two-phase field (copper liquid $_{\text {inatte) }}$.

\section{Selection of System Conditions for Laboratory Tests}

The authors consider that electric furnace slag treatment is best performed at metal saturation conditions due to the lower partial pressure of $\mathrm{S}_{2}$ and $\mathrm{O}_{2}$ associated with this condition. Hence, for the purpose of planning the current tests, prior information on the composition of the phases in the two-phase equilibrium system between the molten copper and the molten matte was required. The Factsage ${ }^{9}$ software (FactSage 6.3; ThermFact Inc./ CRCT, Montréal, Canada) was used to map this system, and the results of these calculations are shown in Fig. 1. The composition field in which the metallic copper is in equilibrium with matte is labeled "copper liquid matte." Within this field, a series of five compositions was chosen, signified by the labels A to E, which provided for both matte and copper phases with an increasing level of $\mathrm{Fe}$ in the order of $\mathrm{A}$ to $\mathrm{E}$. In the current tests, this was achieved by mixing pure $\mathrm{Cu}_{2} \mathrm{~S}, \mathrm{FeS}$, and metallic copper in the required proportions prior to blending with the slag.

For the experimental work, the sulfide/copper mixtures thereby prepared were then mixed with electric furnace slag from the Paipote smelter, together with a given amount of silica sand to obtain two different $\mathrm{Fe} / \mathrm{SiO}_{2}$ ratios in the slag (1.4 and 1.6). The composition of the slag sample received from Paipote is shown in Table I.

Thus, in total, 10 experiments were performed (5 matte compositions and $2 \mathrm{Fe} / \mathrm{SiO}_{2}$ ratios). This was undertaken to better understand the equilibrium conditions relevant to the electric furnace slagcleaning process.

It is known that the copper solubility in slag increases with temperature, ${ }^{6}$ which was also recently discussed by Coursol et al. ${ }^{10}$ Given this, a temperature of $1200^{\circ} \mathrm{C}$ was selected for the experiments. These experiments were carried out in small magnesia crucibles $(3 \mathrm{~mm}$ external diameter $\times 6 \mathrm{~mm}$ high). The crucibles were suspended in a vertical alumina reaction tube with sealed, water-cooled end caps, which were contained within a vertical tube furnace.

As noted earlier, the experiments were made under an inert atmosphere using a controlled flow of argon introduced at the bottom of the reaction tube. The use of inert gas also avoided any oxidation of the melt. All samples were held at temperature for $30 \mathrm{~min}$ and then immediately quenched in water to

Table I. Composition of the Paipote Slag Used in the Experiments*

\begin{tabular}{|c|c|c|c|c|c|c|c|c|c|c|}
\hline Component & Fe (Total) & $\mathbf{Z n}$ & $\mathbf{C u}$ & $\mathbf{S}$ & $\mathbf{P b}$ & MgO & $\mathrm{CaO}$ & $\mathbf{A l}_{2} \mathbf{O}_{3}$ & $\mathrm{SiO}_{2}$ & $\mathrm{Fe}_{3} \mathrm{O}_{4}$ \\
\hline Slag & 48.1 & 2.9 & 0.9 & 0.7 & 0.1 & 1.1 & 1.4 & 2.8 & 28.7 & 7.5 \\
\hline
\end{tabular}

*Slag from the electric furnace at the Paipote smelter, Chile, 2011. 
obtain relatively uniform slag, matte, and copper microstructures to allow microprobe analysis to be carried out. From experience, this holding time was found sufficient for all phases to reach thermodynamic equilibrium, while minimizing any $\mathrm{MgO}$ contamination of the slag by the $\mathrm{MgO}$ crucible dissolution. The $\mathrm{MgO}$ content of the Paipote slag was 1.12 wt.\% (Table I), while the $\mathrm{MgO}$ level at the end of the experiments was generally under 2 wt.\%.

After quenching, each sample was mounted in epoxy for evaluating the composition of each phase using the microprobe.

\section{RESULTS}

\section{Microstructure of Quenched Samples}

The crucible and samples (matte-slag-copper) were prepared for examination using silicon carbide abrasive papers $(125-10 \mu \mathrm{m})$, followed by a final polish using a slurry of fine alumina $\left(\alpha-\mathrm{Al}_{2} \mathrm{O}_{3}\right.$, $0.3 \mu \mathrm{m}$ diameter) to produce a flat mirror surface. The polished surfaces were then examined using a

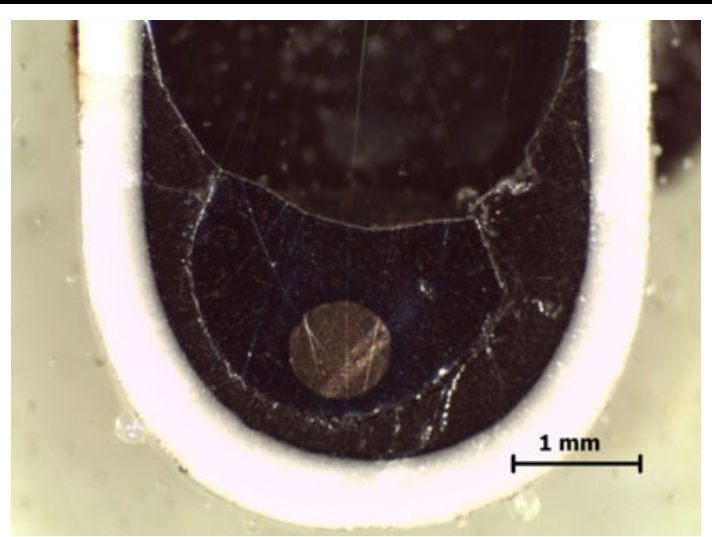

Fig. 2. General aspect of polished crucible and sample (coppermatte-slag mixtures).
Leica EZ4HD and DM750P optical microscope (Leica Microsystems, Wetzlar, Germany), which allowed for the identification of the physical features and the microstructure of the phases formed during smelting and solidification. Figure 2 illustrates the overall features of one of the polished samples.

Microanalyses of polished samples were performed using a JXA JEOL-8900L electron microprobe (JEOL Ltd., Tokyo, Japan) with five wavelength-dispersive spectrometers. The microanalysis of the slag phase was done over a number of $100 \mu \mathrm{m}$ by $100 \mu \mathrm{m}$ areas (normally 10), which were selected at random over a uniform surface of slag, free of entrained matte droplets, metallic copper, or solid magnetite. Figure $3 \mathrm{a}$ and $\mathrm{b}$ presents a general view of the slag surface illustrative of where the microprobe analyses were taken. As shown by the slag microstructure in Fig. 3b, it appears that the sample may not have been quenched fast enough. This was likely due to the design of the sample holder, which had a higher heat capacity than desirable and potentially prevented a very fast quench from occurring. Despite this possible shortcoming, the results of the current work are still considered valid.

During slag solidification, the soluble copper sulfide can be precipitated out, while the soluble $\mathrm{Cu}_{2} \mathrm{O}$ can react with the soluble $\mathrm{FeS}$ in slag to also form $\mathrm{Cu}_{2} \mathrm{~S}$ according to reaction 2 . If the sulfur dissolved in the slag as $\mathrm{FeS}$ is insufficient, then the $\mathrm{Cu}_{2} \mathrm{O}$ can react with the $\mathrm{FeO}$ to form metallic copper, as shown by reaction 3 .

$$
\begin{gathered}
\mathrm{Cu}_{2} \mathrm{O}_{\text {slag }}+\mathrm{FeS}_{\text {slag }}=\mathrm{Cu}_{2} \mathrm{~S}_{\text {matte }}+\mathrm{FeO}_{\text {slag }} \\
\mathrm{Cu}_{2} \mathrm{O}_{\text {slag }}+3 \mathrm{FeO}_{\text {slag }}=\mathrm{Fe}_{3} \mathrm{O}_{4 \text { solid }}+2 \mathrm{Cu}
\end{gathered}
$$

When a molten slag sample is not perfectly quenched, it also can give rise to micron-sized matte and/ or copper droplets that can appear as white "dots" in the slag, as shown in Fig. 3b. The resulting copper
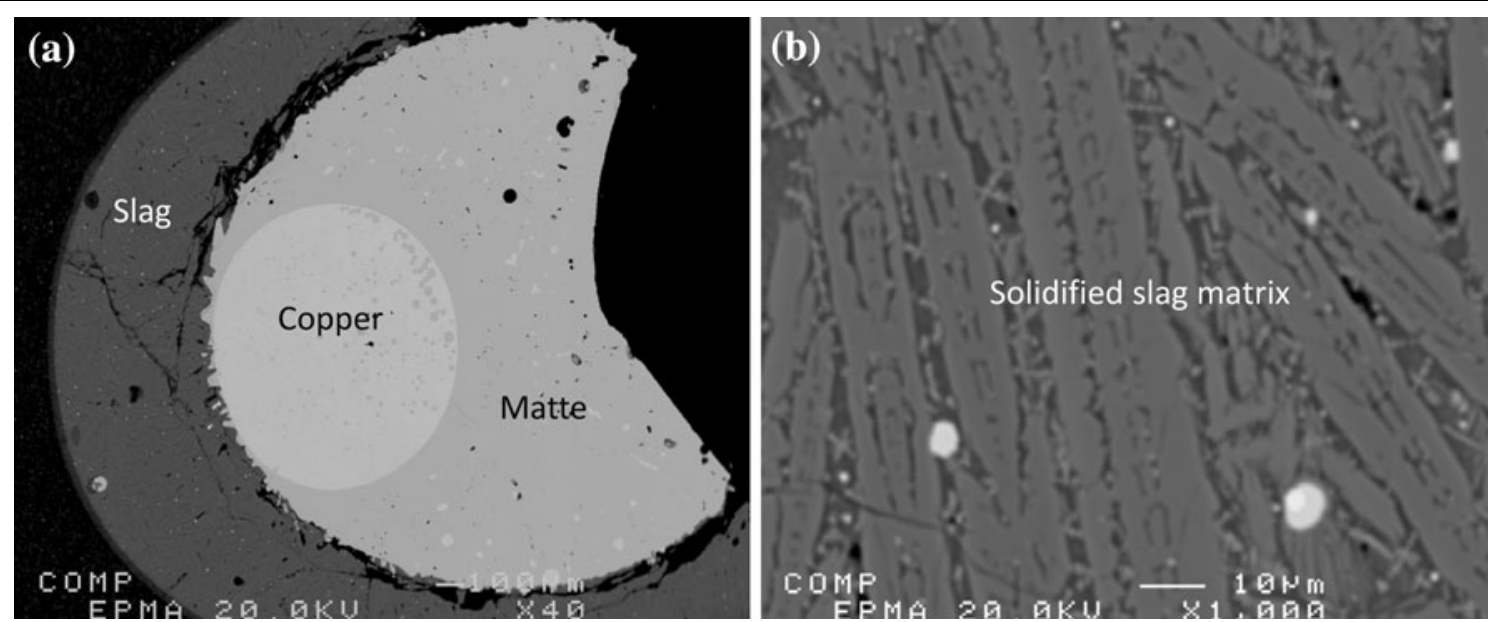

Fig. 3. (a) General aspect of samples 1 through 10 and (b) typical window used for EPMA analysis on the slag phase 
particles in the slag are sometimes referred to as "copper fog" rendering the copper in the slag unrecoverable by milling and flotation. Smelters using slag milling and flotation for slag cleaning generally operate under conditions where most of the copper in slag would tend to form $\mathrm{Cu}_{2} \mathrm{~S}$ upon cooling, although some metallic copper may still form via reaction $3 .^{7}$ Ideally, the slag should be slow cooled to allow most of the copper to form larger matte prills (over $30 \mu \mathrm{m}$ in size), leading to minimal copper levels in the slag tailings.

In order to get a reproducible slag composition, windows of $100 \mu \mathrm{m}$ by $100 \mu \mathrm{m}$ were analyzed. This included small matte and copper droplets formed during cooling but excluded larger matte droplets that could have been present prior to quenching. Any entrained matte in the slag before quenching is generally spherical in shape and are generally between 10 and $100 \mu \mathrm{m}$ in size. The matte formed during solidification is smaller and is found in the glassy phase between olivine platelets and the magnetite crystals formed during slag solidification (see Fig. 3b). The microstructure and composition of these matte types are different and can be discriminated by an experienced mineralogist.

A similar procedure was followed in order to analyze the matte and the copper phases (see Fig. 3a). As evident from Fig. 1, the equilibrium between metallic copper and matte should give a $\% \mathrm{~S}$ level in copper at slightly over 1 wt. $\%$ with a $\% \mathrm{~S}$ in matte of between $20 \mathrm{wt} . \%$ and $23 \mathrm{wt} . \%$ if the microprobe assays are performed correctly (e.g., including all phases formed during cooling but not phases that were intermixed at high temperature). As shown later in this section, the sulfur level in matte and copper were in reasonable agreement with the phase diagram data presented in Fig. 1.

The analytical conditions for the microprobe analysis were $3-\mu \mathrm{m}$ beam size, acceleration voltage of $20 \mathrm{kV}$, beam current of $20 \mathrm{nA}$, and counting time of $20 \mathrm{~s}$ for each element. Several windows of $100 \mu \mathrm{m}$ by $100 \mu \mathrm{m}$ were scanned to obtain representative analysis. The standards used for the slag analysis and the corresponding average detection limits, were as follows: albite $\left(0.03 \% \mathrm{Na}_{2} \mathrm{O}\right)$, chromite $\left(0.03 \% \mathrm{MgO}, 0.04 \% \mathrm{Al}_{2} \mathrm{O}_{3}\right)$, chalcopyrite $(0.02 \% \mathrm{~S}$, $0.03 \% \mathrm{Cu})$, hematite $(0.03 \% \mathrm{FeO})$, pyrope $(0.04 \%$ $\left.\mathrm{SiO}_{2}\right)$, diopside $(0.02 \% \mathrm{CaO})$, willemite $(0.04 \% \mathrm{ZnO})$. Chalcopyrite and copper were used as standards in the microanalysis of the matte and metal phases with detection limits of $0.03 \% \mathrm{~S}, 0.03 \% \mathrm{Fe}$, and $0.04 \% \mathrm{Cu}$, as well as $0.03 \% \mathrm{~S}, 0.03 \% \mathrm{Fe}, 0.04 \% \mathrm{Cu}$, respectively. A summary of the key results is given in Table II, including the analytical results for the slag, matte, and copper phases for tests nos. 1 through 10.

\section{DISCUSSION OF EXPERIMENTAL RESULTS AND INTERPRETATION}

Table II presents the assays for each phase for the 10 tests carried out. For test nos. 1 to 5 , the $\mathrm{Fe} / \mathrm{SiO}_{2}$ ratio ranged from 1.59 to 1.83 with an average of 1.71 compared to the target of 1.6. For test nos. 6 to 10 , the $\mathrm{Fe} / \mathrm{SiO}_{2}$ ratio ranged from 1.37 to 1.51 with an average of 1.43 , which was close to the target of 1.4. It was considered that under the somewhat reducing conditions, some of the magnetite present in the starting Paipote slag (see Table I) could have been reduced by metallic $\mathrm{Fe}$ (see reaction 4), leading to a higher $\% \mathrm{Fe}$ in the slag, thereby raising the $\mathrm{Fe} /$ $\mathrm{SiO}_{2}$ ratio while at the same time lowering the level of $\% \mathrm{Fe}$ in the matte relative to the target. This mechanism may have occurred, potentially leading to a slightly higher $\mathrm{Fe} / \mathrm{SiO}_{2}$ ratio and lower $\% \mathrm{Fe}$ in the matte than anticipated. This may have led to higher $\mathrm{Cu}$ levels in slag; nevertheless, all parameters $\left(\mathrm{Fe} / \mathrm{SiO}_{2}\right.$ ratios, $\% \mathrm{Cu}$ in slag and $\% \mathrm{Fe}$ in matte) were measured at the end of the experiments. Hence, they are considered valid equilibrium conditions.

$$
\mathrm{Fe}_{\text {matte }}+\mathrm{Fe}_{3} \mathrm{O}_{4 \text { slag }}=4 \mathrm{FeO}_{\text {slag }}
$$

While unlikely, if there had been any trace amounts of oxygen in the alumina reaction tube,

Table II. Selected Analytical Results for Slag, Matte, and Copper Compositions for Test Nos. 1 Through 10*

\begin{tabular}{|c|c|c|c|c|c|c|c|}
\hline Test No. & Fe (Matte) & S (Matte) & Cu (Slag) & S (Slag) & $\mathrm{Fe} / \mathrm{SiO}_{2}$ (Slag) & $\mathbf{S}(\mathbf{C u})$ & $\mathbf{F e}(\mathbf{C u})$ \\
\hline 1 & 11.0 & 23.5 & 0.61 & 0.99 & 1.59 & 0.95 & 1.50 \\
\hline 2 & 10.0 & 22.9 & 0.71 & 1.05 & 1.79 & 1.21 & 1.33 \\
\hline 3 & 6.7 & 22.5 & 0.54 & 0.65 & 1.58 & 0.98 & 0.84 \\
\hline 4 & 5.3 & 22.0 & 0.68 & 0.62 & 1.83 & 1.02 & 0.61 \\
\hline 5 & 2.9 & 21.3 & 0.76 & 0.35 & 1.77 & 1.12 & 0.35 \\
\hline 6 & 2.7 & 21.4 & 0.61 & 0.26 & 1.51 & 1.06 & 0.31 \\
\hline 7 & 1.5 & 20.8 & 0.82 & 0.16 & 1.47 & 0.80 & 0.15 \\
\hline 8 & 1.5 & 21.0 & 0.80 & 0.15 & 1.43 & 0.79 & 0.14 \\
\hline 9 & 0.9 & 20.5 & 0.98 & 0.10 & 1.37 & 1.16 & 0.10 \\
\hline 10 & 0.9 & 20.4 & 0.94 & 0.09 & 1.38 & 1.24 & 0.10 \\
\hline
\end{tabular}

*All values are presented as wt.\% except for the $\mathrm{Fe} / \mathrm{SiO}_{2}$ ratio. 
then it is possible that this may have oxidized a small amount of $\mathrm{Fe}$ in matte leading to similar results (higher $\mathrm{Fe} / \mathrm{SiO}_{2}$ than anticipated). Thus, while there was some spread in $\mathrm{Fe} / \mathrm{SiO}_{2}$ ratios, the variability was considered acceptable. The results of matte-metal equilibrium tests (Table II) are presented graphically in Fig. 4.

Figure 4 shows the sulfur and iron levels in metallic copper in equilibrium with a molten matte being close to the expected values. The copper composition is expressed by the lower set of data points shown with a cross symbol. The model used to prepare the phase diagram indicates somewhat higher levels of $\mathrm{Fe}$ in metallic copper. The composition of the matte phase in equilibrium with metallic copper is shown by the upper set of data points shown by a cross in Fig. 4. Even though the experimental points are located above the line, the behavior is similar to that expected by the model. Some limitations on the effectiveness of the quenching rate may have caused the precipitation of small copper droplets, which has already been noted as a potential source of error. Given this, some of the coarser copper prills excluded from the analyzed areas may have led to a bias in the measurements, giving slightly higher sulfur levels in matte. Hence, it is not certain whether the model or the experimental data provide the most reliable data for the sulfur level in matte.

With regard to the copper phase, the current authors consider that the thermodynamic model used here, which suggests a higher level of $\% \mathrm{Fe}$ in the copper phase than that obtained in the current work, was likely less accurate than the data provided by the experimental measurements reported here. It is suggested that a review be undertaken of the input data in the thermodynamic model, taking

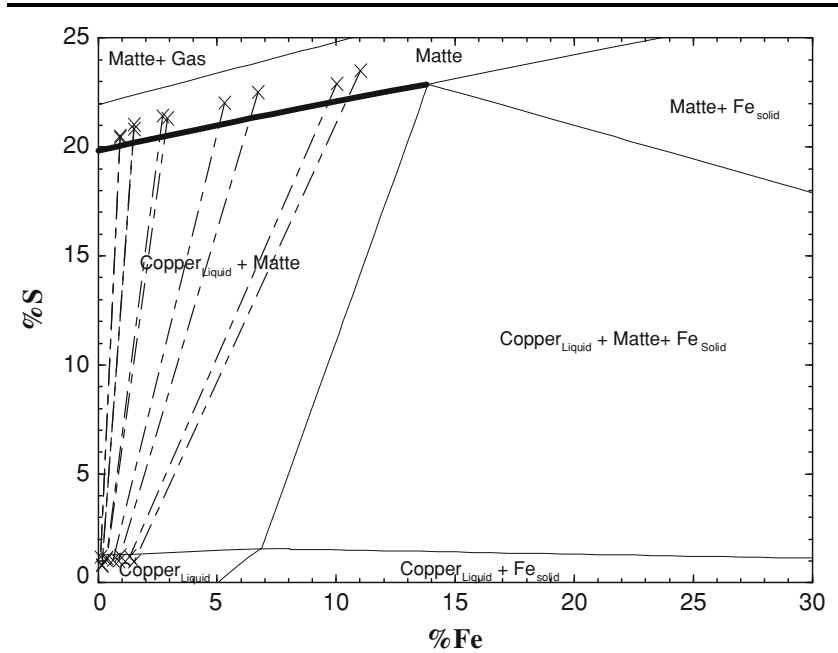

Fig. 4. The copper-rich side of the Cu-Fe-S phase diagram at $1200^{\circ} \mathrm{C}$ as calculated by FactSage ${ }^{8}$ with experimental points from the present study. These are shown by the cross and dotted lines joining the metallic copper and matte composition for each experiment. into account any newly available experimental information. Furthermore, the addition or adjustment of a ternary interaction coefficient for $\mathrm{Fe}-\mathrm{S}-\mathrm{Cu}$ in the metallic copper database may allow for an improved correlation between experimental data and that predicted by the model.

The following section discusses the copper-matteslag equilibrium and highlights the most important variables for process control (or, key performance indicators at the plant) in order to minimize copper losses during electric furnace slag treatment.

\section{Iron Content in Molten Copper and Matte}

The results of the 10 experiments for the $\% \mathrm{Fe}$ in the molten copper phase and in the metalized matte are presented in Fig. 5. It can be seen that a direct relation exists between these two parameters. It is noted that the equilibrium between the molten copper and matte can occur independently of the particular slag chemistry being used.

According to reaction 5, the activity of metallic $\mathrm{Fe}$ (proportional to $\mathrm{Fe}$ dissolved in liquid $\mathrm{Cu}$ ) and the activity of $\mathrm{FeS}$ (proportional to $\mathrm{FeS}$ dissolved in the molten matte) would each increase or decrease together in the presence of metallic copper and matte $\left(\mathrm{a}\left(\mathrm{Cu}_{1}\right) \sim 1\right)$ and molten $\mathrm{Cu}_{2} \mathrm{~S}\left(\mathrm{a}\left(\mathrm{Cu}_{2} \mathrm{~S}\right) \sim 1\right)$. This leads to a constant distribution coefficient of $\mathrm{Fe}$ between the molten matte and metallic copper, as illustrated by the straight line in Fig. 5 .

$$
\mathrm{Fe}_{\text {solid }}+\mathrm{Cu}_{2} \mathrm{~S}_{\text {liquid }}=\mathrm{FeS}_{\text {liquid }}+\mathrm{Cu}_{\text {liquid }}
$$

It should be noted that for matte and copper in equilibrium with molten fayalite slag (where $\left.\mathrm{a}\left(\mathrm{FeO}_{1}\right) \sim 0.5\right)$, the resulting $p\left(\mathrm{O}_{2}\right)$ is quite sensitive to the level of $\mathrm{Fe}$ in the metallic copper (related to $\mathrm{a}\left(\mathrm{Fe}_{1}\right)$ ). This relationship is also expressed by reaction 1 . For example, when the $\% \mathrm{Fe}$ in $\mathrm{Cu}$ rises from $0.2 \mathrm{wt} . \%$ to $2 \mathrm{wt} . \%$ in the presence of molten matte, the $p\left(\mathrm{O}_{2}\right)$ is expected to drop from $\sim 10^{-10}$ atm to $\sim 10^{-12} \mathrm{~atm}$, thus providing better conditions for the reduction of copper oxide and magnetite in the slag.

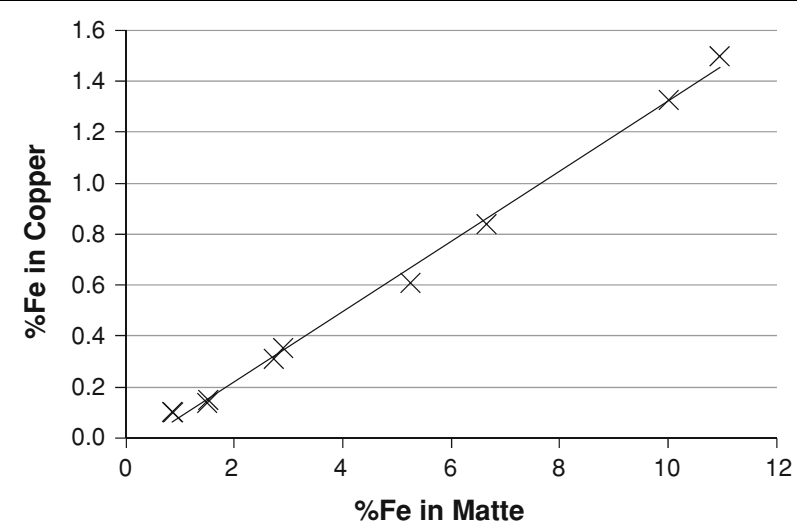

Fig. 5. \% Fe in copper equilibrated with matte containing different levels of $\mathrm{Fe}\left(1200^{\circ} \mathrm{C}\right)$. 
In terms of plant operations, it is suggested that for slag cleaning furnaces, the $\% \mathrm{Fe}$ in the matte be used as a key control parameter, which would correlate directly with the $\% \mathrm{Fe}$ in molten copper. Furthermore, it is suggested that the electric furnace be operated to maintain a shallow layer of molten copper on the furnace hearth. A steel bar inserted into the melt can be used to detect the presence of such a layer. When the bar is introduced into the melt and briefly held there, slag freezes on the upper part of the rod while the underneath layers of copper and matte show a signature on the lower part of the measuring bar, similar to that described for the Noranda Reactor. ${ }^{11}$ It is considered that it would be sufficient to control the sulfur partial pressure in the system by maintaining a small, shallow layer of metallic copper on the furnace hearth. If excess metal is produced, however, then there is a danger that the minor element deportment will be disturbed since a number of minor elements $(\mathrm{Bi}, \mathrm{Pb}, \mathrm{As}, \mathrm{Sb}$, and $\mathrm{Ni}$ ) will preferentially distribute to the molten copper, potentially creating unnecessary minor elements issues.

At $1200^{\circ} \mathrm{C}$, the magnetite solubility limit in typical copper slags under slag-cleaning conditions is around $8 \mathrm{wt} . \%$ (this value is also somewhat dependent on the $\mathrm{Fe} / \mathrm{SiO}_{2}$ ratio in slag). The above magnetite level in fact corresponds to conditions when the $\% \mathrm{Fe}$ in metallic copper is close to $0.3 \mathrm{wt} . \%$. However, by operating with a shallow layer of metallic copper (containing over 0.6 wt.\% Fe with the matte containing over $5 \mathrm{wt} . \% \mathrm{Fe}$ ), it will ensure there is little to no suspended magnetite present in the slag, assuming reasonable reduction and mixing. Under these conditions, the total magnetite level in the slag will correspond to 3 wt.\% to 6 wt. $\% \mathrm{Fe}_{3} \mathrm{O}_{4}$. Reduction with a certain level of mixing within the slag is normally achieved by the addition of a reductant such as petroleum coke, ideally mixed with recycled reverts to help achieve better coke efficiency and minimize the furnace off-take temperature. The addition of pig iron nuggets is also used at some smelters.

Usually, plant trials are carried out to determine the optimum conditions. The effectiveness of magnetite and copper oxide reduction can be validated by plant sampling and by microanalyses. A proper reducing condition, coupled with sufficient settling time to allow for metallic or matte particles to settle, provides the basis for effective pyrometallurgical slag cleaning. Careful management of furnace conditions (power, electrode immersion, slag level, etc.) will help ensure good reduction and settling conditions. In conclusion, as regards the above considerations, good furnace operating practice includes maintaining the $\% \mathrm{Fe}$ in matte over $5 \mathrm{wt} \%$ and holding a small layer of copper on the furnace hearth with proper tuning of the furnace cycle. This should lead to $\mathrm{Fe}_{3} \mathrm{O}_{4}$ levels in the slag below 6 wt.\%. These conditions also help ensure no solid magnetite is present at the slag-matte interface, which can severely hinder proper slag-matte separation.

\section{Dissolved Sulfur in Slag}

As noted earlier, a number of investigators and studies have reported that over a certain range of matte grades (as given by the level of $\mathrm{Fe}$ in matte), the dissolution of $\mathrm{Cu}$ in slag becomes more sulfidic. ${ }^{5,6,10-14}$ Hence, further lowering the matte grade would not necessarily lower copper levels and may even adversely impact the copper loss in slag. The current data for the relationship between $\% \mathrm{Fe}$ in matte and \%S in slag are presented in Fig. 6; this is seen to approximate a linear relationship. This trend is in good agreement with previous work indicating that, as is known, $\mathrm{FeS}$ also dissolves in the slag. ${ }^{7,10,12-14}$ At sulfur levels over $1 \mathrm{wt} \%$ in slag (matte over $10 \mathrm{wt} . \% \mathrm{Fe}$ ), the level of soluble copper in the slag is expected to rise. In the current case, with a metallic phase present, solid metallic Fe can form if the matte contains over 12 wt.\% Fe (see Fig. 4). Therefore, the sulfur in slag could not reach more than $1.2 \mathrm{wt} . \%$ at metal saturation.

It is known that for a constant $\% \mathrm{Fe}$ in matte, a lower sulfur level in slag is achieved at a lower Fe/ $\mathrm{SiO}_{2}$ ratio. Figure 6 illustrates this trend for the two $\mathrm{Fe} / \mathrm{SiO}_{2}$ ratios used in the present tests. Based on the above information, it is recommended to operate toward a lower $\mathrm{Fe} / \mathrm{SiO}_{2}$ ratio to achieve the lowest levels of dissolved copper in slag (present as the oxysulfide complex). On the other hand, the resulting higher silica flux requirement increases both the slag tonnage and requires more smelting heat. Hence, the full economic impact of lowering the $\mathrm{Fe} /$ $\mathrm{SiO}_{2}$ ratio would need to be developed.

\section{Copper Solubility in Slag}

As noted, the ultimate objective of the current work was to determine the minimum level of soluble copper that can be achieved in electric furnace slag cleaning when a small layer of molten copper is present. The lowest copper levels measured in the present experiments were $0.61 \mathrm{wt} . \%, 0.54 \mathrm{wt} . \%$,

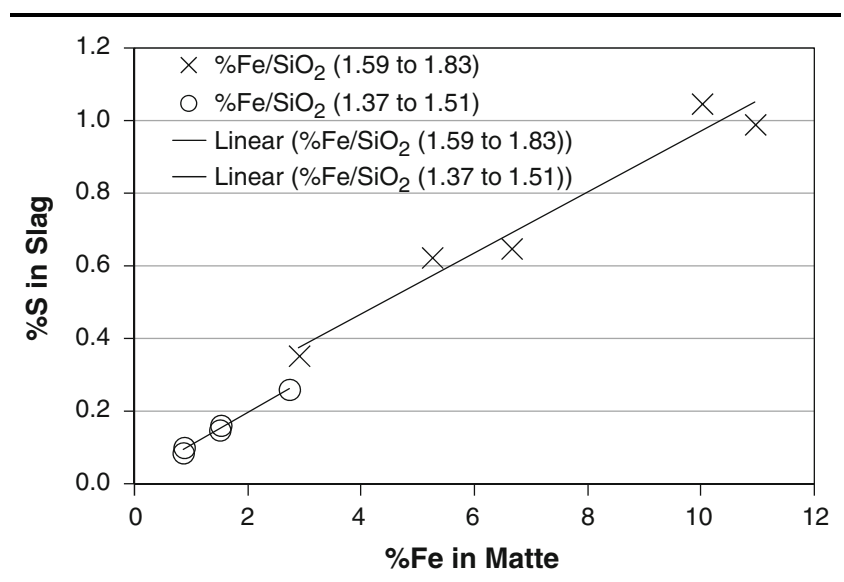

Fig. 6. The observed level of \%S in slag equilibrated with matte containing different levels of $\mathrm{Fe}$ for two different $\mathrm{Fe} / \mathrm{SiO}_{2}$ ratios (temperature $1200^{\circ} \mathrm{C}$ and at metallic copper saturation). 


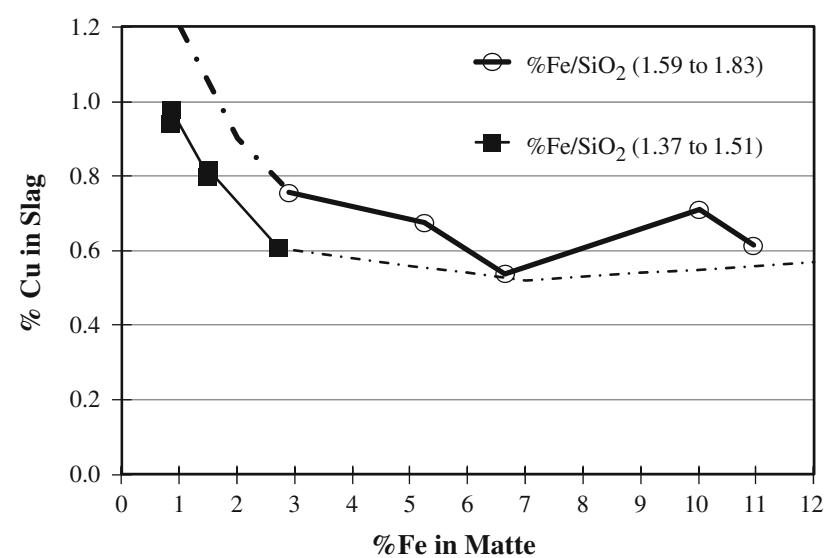

Fig. 7. The level of dissolved copper in slag as a function of $\mathrm{Fe}$ in matte for two different $\mathrm{Fe} / \mathrm{SiO}_{2}$ ratios in slag. The dotted lines represent projected copper levels (temperature $1200^{\circ} \mathrm{C}$ and at metallic copper saturation).

and 0.61 wt.\% $\mathrm{Cu}$ in test nos. 1,3 , and 6 , respectively. From the current results and from the authors' experience, the anticipated minimum copper content in electric furnace slag can therefore be represented as in Fig. 7.

The results suggest that at a given temperature, the minimum level of copper dissolved in electric furnace slag can be obtained with lower $\mathrm{Fe} / \mathrm{SiO}_{2}$ ratios and with a level of $\mathrm{Fe}$ in matte in the range from 6 wt.\% to 9 wt.\%. For an $\mathrm{Fe} / \mathrm{SiO}_{2}$ ratio in slag between 1.2 and 1.4, and at the above suggested range of $\mathrm{Fe}$ in matte, the equilibrium dissolved copper content in slag should be between 0.50 wt. $\%$ and $0.55 \mathrm{wt} . \% \mathrm{Cu}$. It is noted that this represents soluble copper only and does not take into account mechanically entrained matte and/or copper droplets. Operation of the electric furnace under a standard operating procedure will help ensure that the lowest levels of entrained metal/matte can be achieved.

As far as the current authors are aware, the lowest reported copper level in discard electric furnace slag is $0.55 \% \mathrm{Cu}$. This level is obtained in a specific case involving the production of a $\mathrm{Cu}-\mathrm{Pb}$ alloy, ${ }^{15}$ thus aiding the copper losses by lowering the copper chemical activity. The best electric furnace results obtained on more conventional slags are typically in the range of $0.7 \mathrm{wt} . \%$ to $0.75 \mathrm{wt} . \%$ $\mathrm{Cu}$, while most electric furnaces report between 0.75 wt. $\%$ and 1.0 wt. $\% \mathrm{Cu}$. At plants where the electric furnace may be undersized for the tonnage handled or otherwise overstretched, copper losses of up to $1.3 \mathrm{wt} . \%$ have been reported.

\section{CONCLUSIONS AND RECOMMENDATIONS}

The current work has identified the conditions necessary to obtain minimum copper losses during electric furnace cleaning of copper smelting slag. The following recommendations are developed based on the current work combined with the authors' experience in this field:
Operate the furnace with slag temperature between $1220^{\circ} \mathrm{C}$ and $1240^{\circ} \mathrm{C}$ at the end of the reduction cycle. The lower temperature limit will serve to minimize magnetite accumulation at the slag/metal interface and the higher limit is to avoid a high copper solubility in the slag.

Control the $\mathrm{Fe} / \mathrm{SiO}_{2}$ ratio in slag to the target value in the smelting furnace and avoid unnecessarily high ratios.

Maintain a shallow, static layer of molten copper in the electric furnace but avoid steady copper production, which would be detrimental to the smelter minor element balance.

Measure and control the $\% \mathrm{Fe}$ in the electric furnace matte in the range between 6 wt. $\%$ and 9 wt. $\%$ Fe. If needed, Fe can be introduced by adding smelting furnace matte. Add the correct amount of reductant to the electric furnace (for example, as determined based on trials and thermochemical modeling). Ideally, the coke should be added premixed with revert material to help coke digestion and to minimize/avoid combustion in the furnace freeboard. Pig iron can also be added at specific periods in the cycle.

Maintain the magnetite level in the input slag (slag from the smelting and converting units) within a controlled range (as determined based on trials and thermochemical modeling) and specify a maximal converter slag amount to be added per slagcleaning batch or cycle.

Follow a strict standard operating procedure to ensure proper slag reduction and to minimize mechanically entrained matte during slag tapping.

Validate final reduction conditions by ensuring the discard electric furnace slag contains less than 7 wt.\% magnetite.

By following these steps, the total copper loss in the final discard slag should be maintained between 0.7 wt. $\%$ and 0.8 wt.\%. For this situation, the copper losses in the slag are roughly $75 \%$ as dissolved copper and $25 \%$ as entrained copper (or matte). Interestingly, this proportion of soluble copper to an entrained form of copper is quite similar to that identified by Spira and Themelis ${ }^{2}$ in a study on different slags, those for the reverberatory furnace, over 40 years ago.

Laboratory trials, modeling software, and plant sampling experience can be used to quickly diagnose the cause of overly high copper losses in electric furnaces. Following the correct diagnostic procedures, the slag chemistry and the electric furnace standard operating procedure can be optimized to reach a lower copper content in the discard slag.

Kingston Process Metallurgy in Kingston, Ontario, Canada, welcomes proposals from operating copper smelters plants who want to further understand and optimize copper losses in slag in order to improve their copper recoveries. The current work has provided interesting results; nevertheless, with additional sampling at smelter sites, coupled with targeted laboratory experiments, further quantitative data can be developed to improve the value of the information for this important subject. 


\section{ACKNOWLEDGEMENTS}

The authors wish to thank Juan Carlos Vargas and the personnel at the Paipote smelter in Chile for providing the slag sample as well as technical information that has helped to link the fundamentals and applied aspects of this project. The collaboration from Lang Shi, from the McGill University Geology Department, in providing all the microprobe analysis is greatly appreciated.

\section{REFERENCES}

1. R.W. Ruddle, The Physical Chemistry of Copper Smelting (London, UK: The Institution of Mining and Metallurgy, 1953).

2. P. Spira and N.J. Themelis, JOM 21 (4), 35 (1969).

3. R. Schuhmann, Trans. AIME 188, 873 (1950).

4. A. Yazawa and M. Eguchi, Extractive Metallurgy of Copper, Vol. 1, ed. J.C. Yannopoulos and J.C. Agarwal (New York: The Metallurgical Society of AIME, 1976), pp. 3-20.

5. F. Schenalek and I. Imris, Advances in Extractive Metallurgy (London: The Institute of Mining and Metallurgy, 1972), pp. 39-62.
6. M. Nagamori, Met. Trans. B 5B, 531 (1974).

7. M. Nagamori and P.J. Mackey, Met. Trans. B 9B, 255 (1978).

8. P.J. Mackey, Can. Metall. Q. 2, 221 (1982).

9. C.W. Bale, E. Bélisle, P. Chartrand, S.A. Decterov, G. Eriksson, K. Hack, I.-H. Jung, Y.-B. Kang, J. Melançon, A.D. Pelton, C. Robelin, and S. Petersen, CALPHAD 33, 295 (2009).

10. P. Coursol, N. Tripathi, P. Mackey, and T. Leggett, Can. Metall. Q. 49, 255 (2010).

11. L.A. Mills, G.D. Hallett, and C.J. Newman, Extractive Metallurgy of Copper, Vol. 1, ed. J.C. Yannopoulos and J.C. Agarwal (New York: The Metallurgical Society of AIME, 1976), pp. 458-487.

12. N. Cardona, P. Coursol, P.J. Mackey, and R. Parra, Can. Metall. Q. 50, 319 (2011).

13. N. Cardona, P. Coursol, J. Vargas, and R. Parra, Can. Metall. Q. 50, 330 (2011).

14. N. Cardona, P. Coursol, R. Parada, and R. Parra, TMS 2012, Supplemental Proceedings: Volume 2: Materials Properties, Characterization, and Modeling (Warrendale, PA: TMS, 2012), pp. 117-124.

15. L. Byszyński, L. Garycki, Z. Gostyński, T. Stodulski, and J. Urbanowski, Copper 2010 (Hamburg, Germany: GDMB, 2010), pp. 631-644. 